\title{
CERTAIN CONSIDERATIONS ON THE RIGHT TO LEGAL ASSISTANCE IN CIVIL TRIALS
}

\author{
Assoc. Prof. Daniela Cristina CRET, PhD \\ "Vasile Goldiş" Western University of Arad \\ E-mail: danacristinacret@yahoo.com
}

(Received November 2017; Accepted December 2017)

\begin{abstract}
Ensuring access to justice for all litigants, whether individuals or legal persons, and the operation of the principle of equality for parties in a civil trial, involves, among other things, providing appropriate legal assistance, including by granting certain exemptions, reductions, or postponements in the payment of legal fees stipulated by law to those who do not have the financial resources to initiate and sustain a civil trial. Throughout the following we shall emphasise certain aspects of the right to legal assistance, as seen from the perspective of both domestic legislation, and certain European documents.
\end{abstract}

Keywords: legal assistance, civil trial, court of justice, litigant

\section{Introduction}

In order to facilitate access to justice for persons who cannot incur the expenses involved in initiating and conducting a civil trial, the Code of Civil Procedure, which became effective in 2013, as well as other domestic laws and regulations, such as GEO no. 51/2008 on public legal aid in civil matters [1] and Law no. $51 / 1995$ on the organisation and practice of the lawyer's profession [2] (Chapter V, art. 71-85), regulates the right to legal assistance [3].

The coordination and control of the activity of granting public legal assistance is exercised by the Ministry of Justice, and the activity of granting public legal assistance is financed from the state budget, through the budget of the Ministry of Justice [art. 38 para. (1) - (2)].

The right to legal assistance is a fundamental right stipulated by art. 6 of the European Convention on Human Rights, a text which enshrines the right of each person to a fair trial. In this sense, it expressly provides the right of each defendant who does not have the financial resources required to hire a defender to be assisted free of charge by a lawyer ex officio, when this is necessary to achieve the act of justice. In the interpretation of the European Court, the provisions of art. 6 para. (1) of the European Convention on Human Rights concerning legal aid applies both to civil (Golder v. The United Kingdom, 1975) and criminal trials. Regarding civil cases, art. 6 para. (1) provides guarantees where the legal assistance is indispensable for access to the court, having regard to the following considerations: 
legal assistance is mandatory and the complexity of the proceedings or the type of the case requires it [4] (P., C. and S. v. The United Kingdom, 2002).

Under the conditions of art. 90 of the Code of Civil Procedure, legal assistance can be granted only to a person who cannot incur the expenses involved by "initiating and sustaining a civil trial without endangering their own sustenance and that of their family".

The above-mentioned legal provisions confer the right to legal assistance to both individuals [5] and legal entities. With reference to individuals, this right consists of:

a) granting exemptions, reductions, staggered payments or postponements for the payment of legal taxes provided by law;

b) free defence and assistance by a lawyer designated by the Bar;

c) any other ways provided by law.

As regards legal persons [6], in considering the difference in assets they have compared to individuals, legal assistance is less extensive, consisting of facilities in the form of reductions, staggered payments or postponements for the payment of legal stamp duties [7] due for actions and claims filed with courts, under the conditions of the special law (art. 90 of the Code of Civil Procedure).

According to art. 6 of GEO no. 51/2008 the forms under which public legal aid can be granted [8] are:

a) payment of the fee for ensuring representation, legal assistance and, depending on the situation, defence, by a lawyer appointed or elected to secure or defend a right or legitimate interest in court, or to prevent a dispute, referred to as lawyer assistance;

b) payment of the expert, translator or interpreter employed during the trial, with approval of the court or jurisdictional authority, on condition that this payment is incumbent, under the law, on the person requesting public legal aid;

c) payment of the bailiff fee;

d) exemptions, reductions, staggered payments or postponements on the payment of legal fees established by the law, including those occurring during enforcement.

These forms of public legal aid can be given cumulatively or separately. The provisions of the special law state, however, that the maximum limit of the amount of public legal aid that can be granted, cumulatively or separately, in any of the forms mentioned by art. 6 Letters a) - c), cannot exceed, during one year, the equivalent amount of 10 gross minimum wages per country, effective during the year when the request to grant the aid was filed (art. 7).

Legal norms establish that the full payment of public legal aid by the state shall be granted to people who, during the last two months prior to filing the request, had an average net monthly income per family [9] member under 300 lei. At the same time, people whose average net monthly income per family member, during the last 
two months prior to filing the request, is lower than 600 lei, and are granted $50 \%$ of the amount of public legal aid.

In the same vein we can note that granting the aid regardless of the applicant's financial sate is not excluded, in the instance when the special law regulates the right to legal assistance or the right to free legal assistance as a protective measure, under certain special situations, such as: minority, disability, a certain status, or other of this kind. In this instance, in order to benefit from the right to public legal aid, the above-mentioned income-related criteria do not need to be met, but the aid can be granted only for the protection or recognition of certain rights or interests connected to derived from the special situation which determined the legal recognition of the right to legal assistance or to free legal assistance.

Other situations in which public legal aid can be granted under the conditions of GEO no. 51/2008 are those in which the cost of the trial can limit the applicant's effective access to justice, including due to differences in the cost of living between the Member State in which the applicant resides and Romania [art. 8 para. (3)].

As stated above, the general framework of legal assistance is outlined by the norms of the Code of Civil Procedure, which are complemented by GEO no. 51/2008 regarding public legal aid in civil matters, approved by Law no. 193/2008, which implements in Romanian law the Directive 2003/8/EC of the Council of the European Union on improving access to justice in cross-border disputes by establishing common minimum rules on legal assistance in such disputes [10]. According to the provisions of art. 1 of GEO no. 51/2008, the term 'public legal aid' designates that form of assistance granted by the state which seeks to secure the right to a fair trial and to guarantee equal access to the act of justice, in order to legally protect legitimate rights or interests, including for the enforcement of judgements or other enforceable titles.

Both domestic regulations condition the right to obtain state support in initiating and financially sustaining a trial on the endangerment of the applicant's or their family's sustenance by conducting that trial without this support. It is noted, however, that unlike the procedural law, the norms of the special law confer the right to public legal aid only to individuals, and not to legal persons.

The right to legal public aid is terminated as a consequence of the death of the party or an improvement in their financial state, so that they are able to afford the cost of trial.

\section{The procedure for granting legal assistance}

On the grounds of art. 90 of the Code of Civil Procedure, legal assistance can be granted, in full or in part, at any time during the trial, both in the courts of first instance, and in the courts of appeal. 
Making use of this right entails a request being filed by the litigant. According to art. 14 para. (1) of GEO no. 51/2008, the request [11] for legal assistance must be filed in writing [12], and must be addressed to the competent court to solve the case in which the aid is requested [13]; if legal assistance aims to enforce a judgement, the request is within the competence of the court of enforcement [art. 11 para. (1) of GEO no. 51/2008]. Once the request for public legal aid is received, it must be emphasised to the applicant that losing the trial entails incurring the other party's trial expenses and the possibility of returning [14] the amounts received as public legal aid, where the court finds that the request for legal public aid was made in bad faith, by concealing the truth, but, in this last instance, also the payment of a fee consisting of up to 5 times the amount for which they were unduly granted the exemption [art. 14 para. (2) corroborated with art. 17 para. (2) of GEO no. 51/2008].

At the same time, the above-mentioned regulation also comprises other significant specifications in matters of competence; thus, if the previously mentioned criteria cannot lead to determining the competent court, the competence in this matter is stipulated as pertaining to the court in whose jurisdiction the applicant resides. Likewise, in the event of requesting public legal aid in a pending trial, the request or, depending on the situation, requests to grant public legal aid, if the law does not establish otherwise, are in the competence of the court seized to solve the request for summons.

In order to rule on the request for aid in question, the court is given the opportunity to request "any clarification and evidence from the parties, or written information from the competent authorities" (art. 14 para. (3) of GEO no. 51/2008].

The procedural act by which the court resolves the request for public legal assistance [15] is the reasoned conclusion pronounced in the council chamber. The appeal procedure against the rejection of the request for the aforementioned aid is the request for review, and it may be filed within 5 days of the date on which the communication of the conclusion was made.

Where public legal assistance is requested for the purpose of lodging an appeal, a new request must be made. This will be within the competence of the court which delivered the judgment under appeal; it must be resolved by a different panel of judges from that which ruled the case on the merits, and it must be filed within the period when the appeal may be lodged.

The conclusion of approval shall be immediately communicated to the applicant and the Bar of lawyers, the latter having the obligation to appoint within 48 hours a lawyer who can plead before the court of appeal. Information on the appointment and identification of the lawyer must be communicated within 48 hours to the court and to the person requesting assistance, and from the appointment of the lawyer a 
new term will start for lodging the appeal (art. 13 para. (4) and (5) of GEO no. 51/2008].

If the party has not been granted public legal assistance before the appeal, the abovementioned procedure is followed.

In domestic legal practice it was decided that, given the monthly income of the appellant and the amount of the payment obligation imposed on them, it is necessary to provide legal assistance in order not to jeopardize the appellant's existence and to ensure their right of access to justice, conferred by art. 6 para. (1) of the European Convention, since that right cannot be effectively enforced if it is decided that the appellant should pay an amount which is 15 times greater than their income [16].

By way of exception to these provisions, when the judgement given in the case for which the public legal assistance is granted is susceptible to appeal, the public legal assistance provided by lawyer from which the claimant has benefited in the immediately preceding stage of the procedure shall operate ope legis for the drafting of the judgment and grounds of appeal, but also for lodging and sustaining this appeal.

In order to verify and confirm or, where appropriate, designate a lawyer who has the right to plead before the court of appeal, the judgement which is susceptible to appeal, together with the copy of the grant of public legal assistance, must be immediately communicated to the Bar. A new deadline for lodging the appeal will then run from the date of appointment or confirmation of the lawyer.

The court of appeal must verify that the requirements for public legal assistance are maintained. The consequences of non-fulfilment of these conditions are significant: the cessation of the grant of this aid and the obligation on the party to repay, in whole or in part, the costs paid by the state for the lawyer's fee.

The unsuccessful party will be required to pay to the State the expenses for which the opposite party has benefited from exemptions or reductions following the approval of the request for public legal aid.

If the party that received public legal aid loses the trial, the procedural costs that constitute this aid remain with the State. A different solution is settled if the party caused the loss of the trial as a result of negligent behaviour during the trial, or if it was found by court decision that the action was abusive. In such cases, the court may oblige the party who has received public legal assistance to repay, in whole or in part, the expenditure advanced by the State.

According to art. 22 para. (3) of the normative act in question, the amounts representing the lawyer, expert, translator, performer, bailiff or mediator fees are to be paid into bank account, by bank transfer or in cash, through the economic departments of the courts. 


\section{Particular issues related to some forms of legal assistance}

A first form of public legal aid is lawyer assistance [17]. This is regulated by Law no. 51/1995 for the organisation and practice of the lawyer's profession, as republished, with subsequent amendments and completions.

Under art. 90 para. (2) Letter b) of the Code of Civil Procedure, legal assistance refers to defence and assistance provided free of charge by a lawyer appointed by the Bar.

Legal assistance services are organised by the Bar at the headquarters of all courts in the county; they are headed by a final lawyer, appointed by the council of the Bar, and coordinated by a member of the council (art. 79 of Law no. 51/1995).

According to art. 6 from GEO no. 51/2008, another form in which the public legal aid can materialise is the payment of the expert, translator or interpreter fee.

Under the terms of the Ordinance, as a result of the grant of public legal aid, in the form of the payment of the expert, translator or interpreter fees, the conclusion of approval also determines the provisional fee due to them. The court is to decide on the final fee after the service for which the provisional fee was paid has been provided (art. 24). At the same time, the sanctioning of the court's decision on the provisional fee and, depending on the situation, on the amounts representing the difference between the provisional and the final fee as an enforceable title can be noted.

Public legal assistance can also be provided by paying the bailiff fees (art. 26-32 of GEO no. 51/2008).

For the purpose of designating the bailiff, the request for the granting of public legal assistance, together with the conclusion of approval of the assistance, must be submitted to the territorial chamber of bailiffs in the jurisdiction of that court. The governing board of this institution must appoint a bailiff within 3 days. The president of the board shall also communicate the name of the appointed bailiff to the beneficiary of public legal assistance. However, the provisions of the Ordinance also allow the beneficiary of public legal assistance to request the appointment of a particular bailiff themselves, subject to their territorial jurisdiction.

The remedy that an assisted party may have against the manner in which the designated bailiff is performing their professional obligations is the complaint, and it must be addressed to the court that has approved the public legal assistance. Its approval determines the replacement of the bailiff by the governing board of the territorial chamber of bailiffs notified by the court.

Similar to public legal assistance in the form of payment of the expert, translator or interpreter fees, in the case of the bailiff the court is to decide the final fee after the service for which the provisional fee was paid has been provided. Also in the case of this form of public legal assistance, the enforceable status of the court's ruling 
on the provisional fee and, as the case may be, the amounts representing the difference between the provisional and the final fees, is observed.

Another type of public legal aid takes the form of facilities in the payment of court fees (art. 33-34 of GEO no. 51/2008). If the request for the facilitation of payment of court fees is approved, the exemption from payment or, where appropriate, the reduction rate, the payment terms and the amount of the rates must be established by conclusion.

The provisions of the Ordinance establish staggered payment [18] in the case where the court fees due are higher than twice the monthly net family income of the claimant in the month preceding the filing of the request for public legal aid. The staggering must be such that the monthly instalment due does not exceed half of the net family income. However, the possibility for the court to grant a more favourable form of assistance is not excluded.

Under GEO no. 51/2008, assistance may also be provided by a lawyer out of court [19], in which case it can be materialised in one of the following ways: giving consultations, filing requests, petitions, complaints, initiating other legal steps. Also, with the aim of achieving legitimate rights or interests, it may also consist of representation before public authorities or institutions that are not judicial and do not have jurisdiction.

The purpose of out-of-court assistance is to provide the applicant with clear and accessible information, in accordance with the legal provisions in force, for the effective use of the right or interest claimed by them. If the beneficiary of extrajudicial assistance should go to court for the purpose of achieving or defending a right or interest, the provisions of the Ordinance stipulate an interdiction on the lawyer who provided extrajudicial assistance from providing legal aid to the same person, for the achievement of defence of the same right (art. 36 of GEO no. 51/2008).

\section{Conclusions}

In any state of law, access to justice is an essential right of any individual or legal person, an expression of democracy and the rule of law.

With a view to its effective implementation, even for those individuals who do not have sufficient financial resources to benefit from or defend a right in court, the implementation of Council Directive 2003/8/EC on improving access to justice in cross-border disputes was sought, document which regulates certain minimum common rules on the legal assistance provided in such disputes.

Transposition of this Directive into national law is also intended to create a level playing field between Romanian citizens and nationals of other Member States, or persons having their domicile or habitual residence on the territory of a Member 
State and seeking legal aid before courts or other authorities with Romanian jurisdiction.

Having regard to the provisions of GEO no. 51/2008, we consider, de lege ferenda, that certain changes can be made to facilitate access to justice for low-income people. In this respect, we are of the opinion that the threshold of less than 300 lei as net average monthly income per family member in the last two months preceding the filing of the request for the granting of public legal aid, established for its applicants in order for the state to fully cover the expenses necessary for granting this aid, is inadequate, and we propose raising this threshold to 700 lei. In the same vein, the provisions of the Ordinance stipulate that persons whose average net monthly income per family member is less than 600 lei in the last two months preceding the filing of the request are to be granted 50\% of the amount of the public legal aid. Also in this case we believe that the amount is inadequate, and we propose increasing this threshold to 1000 lei.

\section{Bibliography:}

1. Berlingher D., Instituții de drept internațional privat, Editura Limes, Cluj-Napoca, 2014;

2. Boroi G., Stancu M., Drept procesual civil, Editura Hamangiu, 2017;

3. Frenţiu G. C., Băldean D. L., Noul Cod de procedură civilă - Comentat, Editura Hamangiu, 2013;

4. Deleanu I., Ajutorul public judiciar. Legislaţia europenă şi română în materie, in Dreptul, no. 8/2008;

5. Leş I., Noul Cod de procedură civilă. Comentariu pe articole. Art. 1-1133, ediţia a 2-a, Editura C. H. Beck, Bucureşti, 2015;

6. Moldovan F., The family - a biological, social and juridical reality, in Agora International Journal of Juridical Sciences, vol. 8, nr. 1, 2014;

7. Tăbârcă M., Drept procesual civil, vol. I - Teoria generală, Editura Universul Juridic, Bucureşti, 2013;

8. GEO no. 51/2008 on public legal aid in civil matters published in the "Official Gazette of Romania", Part I, no. 327 of 25 April 2008, as subsequently amended and supplemented;

9. Law no. 51/1995 on the organisation and practice of the lawyer's profession published in the "Official Gazette of Romania", Part I, no. 98 of 7 February 2011, as subsequently amended and supplemented.

\section{Notes}

[1] Published in the "Official Gazette of Romania", Part I, no. 327 of 25 April 2008, as subsequently amended and supplemented.

[2] Published in the "Official Gazette of Romania", Part I, no. 98 of 7 February 2011, as subsequently amended and supplemented.

[3] With regard to the general principles of granting free legal assistance see G. C. Frenţiu, D. L. Băldean, Noul Cod de procedură civilă - Comentat, Editura Hamangiu, 2013, p. 141 et seq.

[4] G. C. Frenţiu, D. L. Băldean, op. cit., p. 140. 
[5] On the legal condition of foreigner, see D. Berlingher, Instituții de drept internațional privat, Editura Limes, Cluj-Napoca, 2014, p. 128 et seq.

[6] Regarding legal status of legal persons in Romania, see D. Berlingher, op. cit., p. 126.

[7] As regards these fees, see GEO no. 80/2013 regarding legal stamp duties, published in the "Official Gazette of Romania", Part I, no. 392 of 29 June 2013. According to this normative document, the plaintiff will have the possibility to file, under the law, an request for the granting of facilities for the payment of stamp duty, within 5 days of receipt of the communication [art. 33 para. (2)]. Concerning other aspects regarding the filing of the request for a lawsuit, see G. Boroi, M. Stancu, Drept procesual civil, Editura Hamangiu, 2017, p. 379 et seq.

[8] See I. Deleanu, Ajutorul public judiciar. Legislaţia europenă şi română în materie, in Dreptul, no. 8/2008, pp. 17-47.

[9] Regarding the concept of family, see F. Moldovan, The family - a biological, social and juridical reality, in Agora International Journal of Juridical Sciences, vol. 8, nr. 1, 2014, pp. 104-108.

[10] Published in the Official Journal of the European Union L no. 26 of 31 January 2003.

[11] The request for public legal aid is exempt from legal stamp duties.

[12] I. Leş, Noul Cod de procedură civilă. Comentariu pe articole. Art. 1-1133, ediţia a 2-a, Editura C. H. Beck, Bucureşti, 2015, comment under art. 90.

[13] An affidavit must be annexed to this request, by which the applicant will mention whether they received any public legal aid during the past 12 months, under which form, for what reason, as well as the amount of this aid.

[14] The remedy that may be lodged against the conclusion for refund of the amounts from which the applicant was exempt, as well as the fine, is the request for review. It may be filed within 5 days of the date of communication of the conclusion.

[15] The court shall pronounce itself on the request without summoning the parties [art. 15 para. (1) of GEO no. 51/2008].

[16] Trib. Bistrița-Năsăud, s. civ., conclusion of the Council Chamber of 23 April 2008, in G. C. Frenţiu, D. L. Băldean, op. cit., p. 150.

[17] For detailed aspects regarding this form of legal assistance see M. Tăbârcă, Drept procesual civil, vol. I - Teoria generală, Editura Universul Juridic, Bucureşti, 2013, p. 456 et seq.

[18] The number of monthly instalments cannot be greater than 48 .

[19] It shall also be provided under Law no. 51/1995, as republished, with subsequent amendments and completions. 